\title{
Effect of Aerobic Treadmill Training on Level of Testosterone Hormone and Obesity in Male Children
}

\author{
MAYADA F. MOHAMED, M.Sc.*; EMAN I. EL-HADIDY, Ph.D.*; ZEINAB A. HUSSIEN, Ph.D.* and \\ SAHAR A. KHAIRY, M.D.**
}

The Departments of Physical Therapy for Pediatrics, Faculty of Physical Therapy, Cairo University* and

National Institute of Nutrition**, Egypt

\begin{abstract}
Background: Childhood obesity becomes a major health concern in recent decades, the relationship between obesity and testosterone level is one of the longest running controversies in medical field.

Aim of the Study: was to determine the effect of aerobic exercise on obesity and testosterone level in boys.

Patients and Methods: Thirty boys participated in this study, their ages ranged from 8 to 12 years old and their body mass index percentile equal to or greater than $95 \%$. The participated children were assigned randomly in two equal groups control group A and study group B. Group A received a balanced diet regimen for 12 weeks while Group B received the same balanced diet regimen in addition to aerobic exercise in the form of treadmill training for 50min, 3 days/week for 12 weeks. Weight, height, waist circumference, total and free testosterone were evaluated before and after 12 weeks of treatment for both groups.
\end{abstract}

Results: Non significant differences were found between both groups before treatment in all measuring variables $(p>0.05)$. Post treatment results revealed no statistically significant differences between groups regarding body mass index, and total testosterone $(p>0.05)$, while Significant differences $(p<0.05)$ were observed in waist circumference and free testosterone between both groups in favor of the study group B.

Conclusion: Aerobic exercise in form of treadmill training with balanced diet increase free testosterone level and decrease waist circumference after 12 weeks in obese boys.

Key Words: Testosterone-Male children-Body mass index percentile - Waist circumference-Aerobic exercise.

\section{Introduction}

TIMING of sexual maturation is considered a marker of public health particularly the age at

Correspondence to: Dr. Mayada F. Mohamed, The Department of Physical Therapy for Pediatrics, Faculty of Physical Therapy, Cairo University pubertal onset seems to have markedly declined in girls and in boys with a lesser extent [1]. Testosterone which is an androgenic steroid hormone, plays an important role in the regulation of male reproduction and behaviors, as well as in the maintenance of insulin sensitivity [2]. And its biological effects include promotion of muscle growth. In muscle, testosterone stimulates protein synthesis (anabolic effect) and inhibits protein degradation (anti-catabolic effect) [3] . In males, the principal sources of testosterone are the Leydig cells of the testes, but it is also secreted by the adrenal cortex [4]. Circulating testosterone present in three different forms, including free testosterone (2-3\%), albumin-bound testosterone (20-40\%), and sex hormone-binding globulin (SHBG) bound testosterone $(60-80 \%)$ [5].

According to world health organization (WHO), obesity is one of the most prevalent chronic disorders in children and adolescents [6]. The prevalence of obesity in children and adolescents has been increasing worldwide and its development at an earlier age is reportedly associated with a greater risk of co morbidities and complications [7]. Up to $40 \%$ of overweight children and up to $80 \%$ of overweight adolescents will also be overweight or obese during adulthood [6].

The prevalence of overweight and obesity in boys at childhood and adolescence from developed countries has increased from $16.9 \%$ to $23.8 \%$, while in developing countries estimated increases of $8.1-12.9 \%$ were reported $[8]$. Obese boys and young obese males have significantly lower total and free testosterone (TT and FT) as well SHBG concentrations as compared to lean boys and young lean males [9] because testosterone enhances muscle 
hypertrophy, strength, endurance, and power $[3,10]$ There are different methods to measure the level of obesity as body mass index, waist and hip circumference and triceps fold. Once BMI is calculated for a child or adolescent, it is plotted by age on a sex-specific growth chart. Youth BMIs are then converted to percentiles for their sex and age [11]. Waist circumference has attracted much recent attention as an indicator of fatness and health risks in children and adults. The interest in waist circumference stems from research linking accumulated visceral adipose tissue to increased health risks and metabolic disorders in children and adults. Waist circumference is significantly more efficient than BMI in predicting insulin resistance, blood pressure, serum cholesterol levels, and triglyceride levels [12].

Waist circumference is a better predictor of serum testosterone than body mass index or the waist hip ratio and of cardiovascular disease and diabetes mellitus [13]. Recent studies have shown that low serum testosterone levels were associated with insulin resistance and cognitive dysfunction which are independent risk factors for cardiovascular diseases, type 2 diabetes mellitus and dementia. Therefore, it is important for men to prevent a decline in serum testosterone levels [14]

Aerobic exercise is defined as repetitive movement of large muscle group such as running, cycling, jogging and treadmill training. Most of studies in childhood and adolescent obesity have focused on aerobic exercise, designed primarily to increase caloric expenditure [15].Several studies reported more benefits of combining exercise with caloric restriction on reduction of body weight and body fat and preservation of fat free mass (FFM) [15]. Also it may influence dehydroepiandrosterone, testosterone, progesterone, endorphin, somatotropin as well as leptin and other adipokines, although the examination of the hormonal response to exercise in children and adolescence is limited [17].

Based on literature review, little information is available regarding the long-term effect of aerobic exercise on obesity and testosterone hormone level in prepubertal boys, therefore more studies are needed. So the purpose of the study was to determine the effect of aerobic exercise on obesity and testosterone level in boys.

\section{Subjects and Methods}

Thirty obese boys participated in this study. They were selected from Al-Badrashin Hospital, from May 2016 - March 2017. Their ages ranged from 8 to 12 years old, Their BMI equal to or greater than 95 th percentile, clinical and medical stability state as they didnot receive special medications affecting weight loss or hormonal therapy, no history of cardiac problems or metabolic disorders, musculoskeletal deformities in their posture, free mentality to be able to follow and understand orders and all children were at prepuberty stage.

Children were divided randomly into two groups equals of numbers (control group A and study group B). Randomization process was performed using closed envelopes. The authors proposed 30 closed envelope either each envelope containing a card with either group A or B. Finally each child was asked to draw a closed envelope that contained one of two groups.

The study was approved by the ethics review committee of the faculty of Physical Therapy, Cairo University; all children parents signed a consent form authorizing the participation of their children in this study.

\section{a- For evaluation:}

Height was measured to the nearest $0.1 \mathrm{~cm}$ using a stadiometer as the distance from the top of head to the bottom of the feet with no shoes. Weight was measured to the nearest $0.1 \mathrm{~kg}$ on a digital weight scale in light clothing with no shoes after empting the bladder. BMI was calculated from weight and height, weight $(\mathrm{kg}) /$ height $^{2}\left(\mathrm{~m}^{2}\right)$. Then the BMI number was plotted on the BMI-for-age growth charts for boys. To obtain a percentile ranking [11]

Waist circumference $(\mathrm{cm})$ was measured using an inelastic tape with the subject in a standing position; the tape was applied horizontally midway between the lowest rib margin and the iliac crest [18].

Laboratory analysis: Blood samples were drawn from an antecubital vein of each child in both groups (control and study). Serum free and total testosterone (FT and TT) were measured by radioimmune-assay kit morning fasting sample [19]

\section{$b$ - For treatment:}

Both groups A and B received a balanced diet program for 12 weeks, at first the total caloric intake was calculated and $500 \mathrm{kcal}$ were reduced from the diet consumed according to WHO guidance and in each visit (every week) $500 \mathrm{kcal}$ reduced from diet consumed until it reached 12001600 kilocalories [20]. The optimal macronutrient 
distribution (carbohydrate should approximate 50$55 \%$ of energy, fat less than $35 \%$, and protein $15-$ $20 \%$ of energy [21]. In addition the study group (B) received aerobic exercise in the form of treadmill training on Motorized treadmill 770 (E.220V, $50 \mathrm{HZ}$, and 2.2 Kilowatts) it consists of: Tow lateral hand rails and Control panel. The procedures and goals of exercise were explained to participated boys, each child was instructed to stop walking immediately if he felt pain, fainting or shortness of breath. The exercise training was done for 50 min, 3 days/ week according to Song et al., [22] as follow:

A- Warming up: At the beginning of the exercise program, include walking on the treadmill for 10 minutes at speed $1.5 \mathrm{~km} / \mathrm{h}$ with zero inclination.

$B$-Active phase: 30 minutes in the form of walking/running on electric treadmill with zero inclination. The intensity of treatment gradually from 60 to $70 \%$ of maximum heart rate for each child.

C-Cooling down: Included walking on the treadmill for 10 minutes at speed $1.5 \mathrm{~km} / \mathrm{h}$ with zero inclination and gradually decreased speed until reach zero.

The equation of maximum heart rate for children is $208-(0.7 \mathrm{x}$ age $)$ according to Machado and Denadai, [23]

\section{Statistical analysis:}

Descriptive statistics were done in the form of mean and standard deviation of all measuring variables BMI, waist circumference TT and FT, in addition to the age, weight and height. Paired t- test was conducted to compare between pre and post treatment mean values in each group. Un paired $t$-test was conducted to compare between pre and post treatment mean values of all measuring variables between both groups. The level of significant for all statistical tests was set at $p<0.05$. All statistical analysis was conducted through SPSS (Version 23.0. Armonk, NY, USA).

\section{Results}

The children characteristics are presented in Table (1). The two groups were compared on demographic variables and base line scores. There were no significant differences between both groups before treatment $(p>0.05)$.

Comparisons between pretreatment and post treatment revealed no statistically significant dif ferences $(p>0.05)$ between group A and group B regarding $\mathrm{BMI}$, weight loss and total testosterone Table (2). But a Significant difference $(p<0.05)$ was observed in waist circumference and FT between both groups when comparing the post treatment measurements in favor of the study group B (Table 2).

In the control group, when the pretreatment mean values were compared to post treatment mean values they revealed a significant improvement $(p<0.05)$ of BMI, weight and waist circumference and there is no significant difference $(p>0.05)$ in T.T and FT, while in the study group; there was a significant difference $(p<0.05)$ of mean value between pre and post mean values of all measuring variables (BMI, weight, waist circumference, TT and FT) Table (2).

Table (1): Descriptive data of both groups.

\begin{tabular}{llllll}
\hline \multirow{2}{*}{ Variables } & \multirow{2}{*}{$\begin{array}{c}\text { Group A } \\
\text { Mean } \pm \text { SD }\end{array}$} & $\begin{array}{c}\text { Group B } \\
\text { Mean } \pm \text { SD }\end{array}$ & \multicolumn{2}{c}{ Comparison } & S \\
\cline { 5 - 6 } Age (yrs) & $9.96 \pm 1.14$ & $9.68 \pm 1.22$ & 0.645 & 0.524 & NS \\
Weight $(\mathrm{Kg})$ & $54.62 \pm 7.38$ & $52.15 \pm 10.16$ & 0.762 & 0.452 & NS \\
Height $(\mathrm{cm})$ & $142.97 \pm 7.07$ & $139.07 \pm 8.54$ & 1.363 & 0.184 & NS \\
BMI $(\mathrm{Kg} / \mathrm{m} 2)$ & $26.83 \pm 2.91$ & $26.79 \pm 3.67$ & 0.028 & 0.978 & NS \\
Waist circumference $(\mathrm{cm})$ & $83 \pm 5.88$ & $82.73 \pm 4.88$ & 0.135 & 0.893 & NS \\
TT $(\mathrm{ng} / \mathrm{ml})$ & $0.14 \pm 0.10$ & $0.17 \pm 0.14$ & 0.730 & 0.471 & NS \\
FT (pg/ml) & $0.40 \pm 0.32$ & $0.41 \pm 0.31$ & 0.143 & 0.887 & NS \\
\hline *BMI : Body mass index. & TT: Total testosterone. & FT : Free testosterone. & SD: Standard deviation. & \\
$p \quad$ S : Significance. & NS : Non-significant. & & &
\end{tabular}


Table (2): Comparison between pre and post treatment mean values in all measuring variables within and between groups.

\begin{tabular}{|c|c|c|c|}
\hline \multirow{2}{*}{ Variables } & \multicolumn{2}{|c|}{ Pre/post (Mean value \pm SD) } & \multirow{2}{*}{$\begin{array}{l}\text { Post treatment Mean } \\
\text { value } \pm \text { SD A\&B }\end{array}$} \\
\hline & Group A & Group B & \\
\hline $\mathrm{BMI}\left(\mathrm{Kg} / \mathrm{m}^{2}\right)$ & $\begin{array}{l}26.83 \pm 2.91 / \\
23.43 \pm 2.83 \\
p \text {-value } 0.001 *\end{array}$ & $\begin{array}{l}26.79 \pm 3.67 / \\
21.27 \pm 7.02 \\
p \text {-value } 0.002 *\end{array}$ & $\begin{array}{l}\text { Group A } 23.43 \pm 2.83 \\
\text { Group B } 21.27 \pm 7.02 \\
p \text {-value } 0.278\end{array}$ \\
\hline Weight ( Kg) & $\begin{array}{l}54.62 \pm 7.38 / \\
47.95 \pm 6.62 \\
p \text {-value } 0.001^{*}\end{array}$ & $\begin{array}{l}52.15 \pm 10.16 / \\
44.30 \pm 10.33 \\
p \text {-value } 0.001 *\end{array}$ & $\begin{array}{l}\text { Group A } 47.95 \pm 6.62 \\
\text { Group B } 44.30 \pm 10.33 \\
p \text {-value } 0.259\end{array}$ \\
\hline Waist circumference $\left(\mathrm{Cm}^{2}\right)$ & $\begin{array}{l}83 \pm 5.88 / \\
76.97 \pm 5.14 \\
p \text {-value } 0.001^{*}\end{array}$ & $\begin{array}{l}82.73 \pm 4.88 / \\
72.37 \pm 3.32 \\
p \text {-value } 0.001 *\end{array}$ & $\begin{array}{l}\text { Group A } 76.97 \pm 5.14 \\
\text { Group B } 72.37 \pm 3.32 \\
p \text {-value } 0.007 *\end{array}$ \\
\hline TT (ng/ml) & $\begin{array}{l}0.14 \pm 0.10 / \\
0.21 \pm 0.22 \\
p \text {-value } 0.199\end{array}$ & $\begin{array}{l}0.17 \pm 0.14 / \\
0.33 \pm 0.20 \\
p \text {-value } 0.001 *\end{array}$ & $\begin{array}{l}\text { Group A } 0.21 \pm 0.22 \\
\text { Group B } 0.33 \pm 0.20 \\
p \text {-value } 0.124\end{array}$ \\
\hline $\mathrm{FT}(\mathrm{pg} / \mathrm{ml})$ & $\begin{array}{l}0.40 \pm 0.323 / \\
0.36 \pm 0.299 \\
p \text {-value } 0.636\end{array}$ & $\begin{array}{l}0.41 \pm 0.314 / \\
0.68 \pm 0.304 \\
p \text {-value } 0.001 *\end{array}$ & $\begin{array}{l}\text { Group A } 0.36 \pm 0.299 \\
\text { Group B } 0.68 \pm 0.304 \\
p \text {-value } 0.008^{*}\end{array}$ \\
\hline
\end{tabular}

BMI: (Body mass index). TT: (Total testosterone). FT: (Free testosterone). $\quad p$ : Probability * Significant difference.

\section{Discussion}

Childhood and adolescent obesity is widely perceived as one of the most important public health challenges, as obesity is associated with significantly increased risk of a range of morbidities and mortality, including type II diabetes, cardiovascular disease and cancer [24]. Obesity is associated with a reduction of serum testosterone, and, vice versa, a reduction in serum testosterone is associated with obesity and features of the metabolic syndrome [13]

The BMI percentile was decreased in children of both groups but with insignificant difference between control group (diet group) and study group (diet and treadmill training). This loss in weight of both groups is due to balanced diet control. According to McAuley et al., reported that lowcarbohydrate and fat diets are effective for weight loss [25]. Also Bazzano et al., [26] mentioned that diets reduce body fat $\%$ and improve lipid profile as cardiovascular risk factors. Previous studies demonstrated that both diets improved lipid profiles with reductions in total cholesterol, triglycerides and low-density lipoprotein cholesterol (LDL-C).

The waist circumference showed significant decrease in both groups with more decrease in study group with $p<0.05$ that aerobic exercises may reduce body fat and increase lean body mass, thereby reducing the risk of overweight and obesity in adulthood and the subsequent premature morbidity and mortality [27]. Several randomized con- trolled studies have shown that aerobic types of exercise are protective against age-related increases in visceral adiposity in growing children and adolescents [28]. Also these results supported by Lee et al., [29]. who reported that After 3 months, both aerobic and resistance exercise groups show a significant reduction in waist circumference in obese adolescent boys .

Regarding the TT and FT, there were significant increase on both after treatment program in both groups, while the FT increase only after aerobic treadmill training when compared to group of diet only. This might be due to weight loss on both groups and decrease in BMI percentile and decrease in waist circumference as decreasing abdominal obesity increasing insulin sensitivity, in hence; decrease insulin resistance which associated with increase testosterone level [28]. These supported by the results of Mohr et al., [30] study which revealed strong negative correlation between all measures of adiposity [BMI, and waist circumference, waist to-hip ratio (WHR)] with SHBG levels. Free or non-SHBG-bound testosterone levels.

Rising level of testosterone supported by various studies that exploring the effects of exercise on androgens, demonstrate that exercise bouts are associated with an acute transient increase in testosterone; The effect of long-term, moderate intensity, aerobic exercise on hormone levels in children has not been well studied [31]. Testosterone level is correlated with leptin that could be increased 
by increase weight loss and decrease BMI percentile that come with Alghadir et al., [32] results Leptin is the protein released from the white adipose tissue and its blood level depends on fat stores as a regulator of food intake and energy expenditure, its concentration increases exponentially with the increase in body adipose tissue and vice versa.

The significant increase of FT after aerobic exercise may be due to additive benefits of combining exercise with caloric restriction on reduction of body weight and body fat and preservation of fat free mass (FFM) as compared to diet alone may be associated with the weight change as testosterone is related to muscle mass [15]. As well the increase in free testosterone may be related to changes in the binding affinity of the carrier protein because of change in $\mathrm{pH}$ and temperature due to exercise. This in turn would have decreased the level and uptake of the carrier protein to testosterone hormone which would be finally liberated as free hormones [32]. The mechanisms of the increase in resting testosterone following exercise training is not clear, researchers have suggested multiple possible mechanisms ie; a stimulation of testosterone secretion by promoting the dilatation of vessels and increased blood flow in the testes, increased LH production and, an increase in lactate accumulation and its direct stimulatory effect on testosterone secretion. It has also been suggested that an increase in sympathetic function due to training, which may lead to a more rapid testosterone response [33] Also more marked obesity however is associated with an unequivocal reduction of free testosterone levels, that may be due to the dominant suppression occurs at the hypothalamic pituitary level. This may be because adipose tissue, especially when in the inflamed, insulin resistant state, expresses aromatase which converts testosterone to estradiol (E2) [34]

On the other hand the results of this study disagree with Hawkins et al., [31] studied the effect of exercise on serum sex hormones in men after 12-month randomized clinical trial and revealed that there were no significant differences between exercisers and controls for testosterone and free testosterone.

The level of TT and FT in both groups was represented within normal ranges that contradict with Reinehr et al., [35] when comparing androgens between obese and normal-weight prepubertal boys, was found that moderately increased testosterone levels in obese. Also, after the intervention program in form of outpatient 1-yr intervention program based on exercise, behavior, and nutrition therapy (high-carbohydrate low-fat diet), the results of obese prepubertal boys losing substantial weight showed a significant decrease in testosterone levels $(p<0.05)$, while testosterone showed significant increase after decrease in BMI of our study. As well our results disagree with Kraemer et al., [36], examined the physiological effects of a weightloss dietary regimen with or without exercise in men and found that there were no significant changes in basal concentrations of serum glucose, cortisol, testosterone, and high density lipoprotein (HDL) cholesterol for any of the groups (a dietonly, a diet group that performed aerobic exercise three times per week and a diet group that performed both aerobic and strength training three times per week.

\section{Conclusion:}

Data concluded from this study that a dietary regimen in conjunction with aerobic treadmill training increasing weight loss, decreasing waist circumference that indicate decrease visceral fat to more extent that induced by diet alone. Also, it has an effect on serum testosterone level as increasing free testosterone. This study was limited by low sample size and short time period of follow up so further longitudinal studies are needed taking boys in prepuberty and puberty stages with normal and abnormal testosterone level.

\section{Acknowledgment:}

The authors thank the participating boys and their parents for good cooperation and follow all instructions.

\section{Conflict of interest:}

No potential conflict of interest relevant to this article was reported.

\section{References}

1- SØRENSEN K. and JUUL A.: BMI percentile-for-age overestimates adiposity in early compared with late maturing pubertal children. Eur. J. Endocrinol., 173: 227$235,2015$.

2- PINTANA H., CHATTIPAKORN N. and CHATTIPAKORN S.: Testosterone deficiency, insulin-resistant obesity and cognitive function .J. Metab Brain Dis .,30:853-876, 2015.

3- VINGREN J.L., KRAEMER W.J., RATAMESS N.A., ANDERSON J.M., VOLEK J.S. and MARESH C.M.: Testosterone Physiology in Resistance Exercise and Training the Up-Stream Regulatory Elements. J. Sports Med., 40 (12): 1037-1053, 2010.

4- THOMAS NE., LEYSHON A., HUGHES M G., DAVIES B., et al.: The effect of anaerobic exercise on salivary cortisol, testosterone and immunoglobulin (A) in boys aged 15-16 years. Eur. J. Appl Physiol., 107: 455-461, 2009 
5- KAPOOR D., ALDRED H., CLARK S., CHANNER K.S., JONES T.H.: Clinical and biochemical assessment of hypogonadism in men with type 2 diabetes: Correlations with bioavailable testosterone and visceral adiposity. Diabetes Care., 30 (4): 911-7, 2007.

6- KIM S.E., JANG J.W., AHN M.B., KIM S.H., CHO W.K., CHO K.S., PARK S.H., JUNG M.H. and SUH B.K.: The association between skeletal maturation and adrenal androgen levels in obese children and adolescents. Ann Pediatr Endocrinol. Metab., Jun., 22 (2): 108-114, 2017.

7- RALF SCHIEL, ALEXANDER KAPS, GÜNTER STEIN and ANTJE STEVELING: Identification of Predictors for Weight Reduction in Children and Adolescents with Overweight and Obesity (IDA-Insel Survey. Healthcare (Basel)., Mar., 4 (1): 5, 2016.

8- KELLEY G.A. and KELLEY K.S.: Exercise and BMI zscore in overweight and obese children and adolescents: Protocol for a systematic review and network metaanalysis of randomised Trials. B.M.J. Open., 6: e011258, 2016.

9- MOGRI M., DHINDSA S., QUATTRIN T., GHANIM H., and DANDONA P.: Testosterone concentrations in young pubertal and post-pubertal obese males. Clin, Endocrinol, (Oxf)., April, 78 (4): 593-599. doi:10.1111/cen. 12018, 2013.

10- RICHMOND E. and ROGOLA D.: Endocrine Responses to Exercise in the Developing Child and Adolescent. Sports Endocrinology. Front Horm Res. Basel, Karger,; Vol 47, pp 58-67 (DOI: 10.1159/000445157), 2016.

11- NIHISER A.J., LEE S.M., WECHSLER H., MCKENNA M., ODOM E., REINOLDC, THOMPSON D. and GRUMMER-STRAWN L.: Body mass index measurement in schools. J. Sch. Health., 77: 651-671, 2007.

12- KREBS N.F., HIMES J.H., JACOBSON D., NICKLAS T. A., GUILDAY P. and STYNE D.: Assessment of Child and Adolescent Overweight and Obesity. Pediatrics, 120: S 193, 2007.

13- HAIDER A., SAAD F., DOROS G. and GOORENE L.: Hypogonadal obese men with and without diabetes mellitus type 2 lose weight and show improvement in cardiovascular risk factors when treated with testosterone: An observational study. Obes. Res. Clin. Pract., Jul-Aug., 8 (4): e339-49,2014.

14- KUMAGAI H., MIYAKI A Z., YOSHIKAWA T., TSUJIMOTO T., TANAKA K. and MAEDA S.: Increased physical activity has a greater effect than reduced energy intake on lifestyle modification induced increases in testosterone. J. Clin. Biochem Nutr. Jan., 58 (1): 84-9. doi: 10.3164/ jcbn. 15-48, 2016.

15- GELIEBTER A., OCHNER C.N., DAMBKOWSKI C.L. and HASHIM S A.: Obesity-Related Hormones and Metabolic Risk Factors: A Randomized Trial of Diet plus Either Strength or Aerobic Training versus Diet Alone in Overweight Participants. J. Diabetes. Obes., 1 (1): 1-7, 2014.

16- WATTS K., JONES T.W., DAVIS E.A. and GREEN D.: Exercise Training in Obese Children and Adolescents. J. Sports. Med., 35 (5): 375-392. 2005.

17- RIDDELL M.C.: endocrine response and substrate utilization during exercise in children and adolescents. J. Appl. Physiol., 105: 725-733, 2008.
18- SARRÕ Á., MORENO L.A., GARCÕ L.Á., FLETA J. MORELLO N' M.P. and BUENO M.: Body mass index, triceps skinfold and waist circumference in screening for adiposity in male children and adolescents. Acta. Paediatr., 90: 387-92, 2001

19- ENGLISH M.K., MANDOUR O., STEEDS P.R., DIVER J.M., JONES H.T. and CHANNER S.K.: Men with coronary artery disease have lower levels of androgens than men with normal coronary angiograms. European. Heart Journal, 21, 890-894,2000.

20- World Health Organization (WHO): TECHNICAL Report Series. Obesity: Preventing and managing the global epidemic. Report of a WHO consultation. WHO Tech. Rep. Ser., 894:1-253, 2000.

21- SMARTA C.E., ANNANB F., BRUNOC L.P., HIGGINSD L.A. and ACERINIE C.L.: Nutritional management in children and adolescents with diabetes. Pediatric Diabetes., 15 (Suppl. 20): 135-153, 2014.

22- SONG K., STEBBINS L.C., KIM K T., KIM B.H., KANG J.H. and CHAI H.J.: Effects of 12 weeks of aerobic exercise on body composition and vascular compliance in obese boys. J. Sports. Med. Phys. Fitness., 52: 522-9, 2012.

23- MACHADO F.A. and DENADAI B.S.: Validity of Maximum Heart Rate Prediction Equations for Children and Adolescents. Arq. Bras. Cardio., 97 (2): 136-140, 2011.

24- SIMMONDS M., LLEWELLYN A., OWEN G.C. and WOOLACOTT N.: Predicting adult obesity from childhood obesity: A systematic review and meta-analysis., pp., 95-107. ISSN 1467-7881, 2015.

25- MCAULEY K.A. 1, SMITH K.J., TAYLOR R.W., MCLAY R.T., WILLIAMS S.M. and MANN J.I.: Long-term effects of popular dietary approaches on weight loss and features of insulin resistince. Int. J. Obes. (Lond), Feb., 30 (2): 342-9, 2006.

26- BAZZANO L.A., T. HU, K. REYNOLDS, L. YAO, C. BUNOL, Y. LIU, C.S. CHEN, M.J. KLAG, P.K. WHELTON and J. HE.: Effects of low carbohydrate and lowfat diets: A randomized trial. Ann. Intern. Med., 161 (5): 309-318, 2014.

27- GEORGE A., KELLE Y., KRISTI S. KELLE Y. and RUSSELL R.P.: Effects of exercise on BMI z-score in overweight and obese children and adolescents: A systematic review with meta-analysis. BMC Pediatrics, 14: 225,2014

28- KIMY M. and LEE S.J.: Physical activity and abdominal obesity in youth. Applied Physiology, Nutrition, and Metabolism., 34 (4): 571-581, 2009

29- SOJUNG L., FIDA B., TAMARA H., JENNIFER L.K., CHRIS B. and SILVA A.: Effects of Aerobic Versus Resistance Exercise Without Caloric Restriction on Abdominal Fat, Intrahepatic Lipid, and Insulin Sensitivity in Obese Adolescent Boys.A Randomized, Controlled Trial. Diabetes Nov., 61 (11): 2787-2795, 2012.

30- MOHR B.A., BHASIN S., LINK C.L., O'DONNELL A.B. and MCKINLAY J.B.: The effect of changes in adiposity on testosterone levels in older men: Longitudinal results from the Massachusetts Male Aging Study. Eur. J. Endocrinol. Sep., 155 (3): 443-52, 2006.

31- HAWKINS V.N., FOSTER-SCHUBERT K., CHUBAK J., SORENSEN B., ULRICH C.M., STANCYZK F.Z., 
PLYMATE S., STANFORD J., WHITE E., POTTER J.D. and MCTIERNAN A.: Effect of Exercise on Serum Sex Hormones in Men: A 12-Month Randomized Clinical Trial. Med. Sci. Sports. Exerc. February, 40 (2): 223 233,2008

32- ALGHADIR H. AHMAD, GABR A. SAMI and ALY A. FARAG: The effects of four weeks aerobic training on saliva cortisol and testosterone in young healthy persons. J. Phys. Ther. Sci. Jul., 27 (7): 2029-2033, 2015.

33- SHAKERI N., NIKBAKHT H., AZARBAYJANI M.A and AMIRTASH M. A.: The effect of different types of exercise on the testosterone/cortisol ratio in untrained young males. Annals of Biological. Research, 3 (3): 14521460, 2012

34- FUI M NG TANG, DUPUIS PHILIPPE and GROSSMANN MATHIS: Lowered testosterone in male obesity: Mechanisms, morbidity and management. Asian. J. Androl. Mar-Apr., 16 (2): 223-231, 2014
35- REINEHR T., DE SOUSA G., ROTH L C. and ANDLER W.: Androgens before and after Weight Loss in Obese Children. 2005. The Journal of Clinical Endocrinology $\&$ Metabolism., October, Volume 90, Issue 10, Pages, 5588-5595, 2005 .

36- KRAEMER W.J., VOLEK J.S., CLARK K.L., GORDON S.E., PUHL S.M., KOZIRIS L.P., MCBRIDE J.M., TRIPLETT-MCBRIDE N.T., PUTUKIAN M., NEWTON R.U., HÄKKINEN K., BUSH J.A. and SEBASTIANELLI W.J.: Influence of exercise training on physiological and performance changes with weight loss in men. Med. Sci. Sports Exerc. Sep., 31 (9): 1320-9, 1999.

37- BIRKEBEK H.N., LANGE A., HOLLAND-FISCHER P., KRISTENSEN K., RITTIG S., VILSTRUP H., HANDBERG A. and GRONBAEK H.: Effect of weight reduction on insulin sensitivity, sex hormone-binding globulin, sex hormones and gonadotrophins in obese children. European Journal of Endocrinology, 163 895-900, 2010.

\title{
تأثير تمرينات السير الكهربائى الهوائية

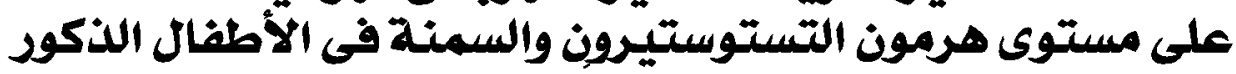

\author{
الهدف من الدراسة : هو تحديد تأثير التمارين الهوائية على مستوى هرمون التستوستيرن والسمنة فى الاطفال الذكو. \\ طريقة الدراسة: تضمنت الدراسة .ب ذكر تتراوح اعمارهم من ^ الى با سنة ومؤشر كتلة الجسم المنْى لديهم يساوى او اكبر من 90٪.

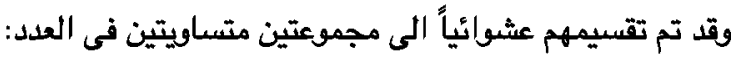

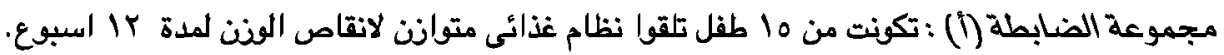

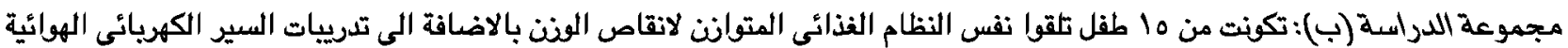

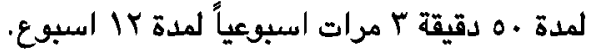 \\ القياسات: تم قياس الوذن، الطول، مؤشر كتلة الجسم المئوى، محيط الخصر ومستوى هرمون التستوستيرن الكلى والحر فى الدم.

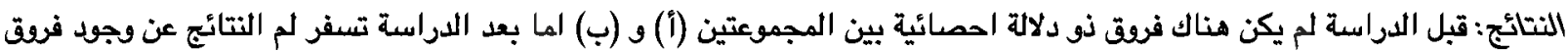

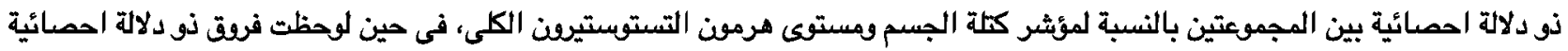

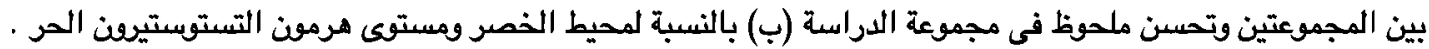 \\ الخلاصة: اسفرت هذه الدراسة على ان تطبيق برنامج غذائي متوانن لانقاص الوذن بالاضافة الى تدريبات السير الكهريائى الهوائية له

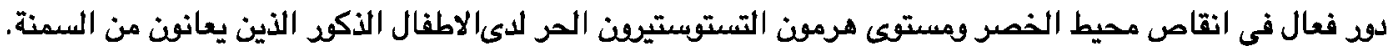

